\title{
CORRIGENDA
}

\section{A multiparameter flow cytometry immunophenotypic algorithm for the identification of newly diagnosed symptomatic myeloma with an MGUS-like signature and long-term disease control}

B Paiva, M-B Vídriales, L Rosiñol, J Martínez-López, M-V Mateos, EM Ocio, M-Á Montalbán, L Cordón, NC Gutiérrez, L Corchete, A Oriol, M-J Terol, M-A Echeveste, R De Paz, F De Arriba, L Palomera, J de la Rubia, J Díaz-Mediavilla, M Granell, A Gorosquieta, A Alegre, A Orfao, J-J Lahuerta, J Bladé and JF San Miguel on behalf of the GEM (Grupo Español de MM)/PETHEMA (Programa para el Estudio de la Terapéutica en Hemopatías Malignas) cooperative study group

Leukemia (2013) 27, 2112; doi:10.1038/leu.2013.213

Correction to: Leukemia (2013) 27, 2056-2061; doi:10.1038/ leu.2013.166

Since the publication of this article, the authors have noticed an omission in the Acknowledgements section, namely that the following had not been included: Asociación Española Contra el Cáncer (AECC; GCB120981SAN), Spain.
This has now been added to the Acknowledgements, and the corrected article appears in this issue. The html and online pdf versions have also been rectified, and now carry the correct paper.

The authors would like to apologise for any inconvenience this may have caused.

\section{Mayo prognostic model for WHO-defined chronic myelomonocytic leukemia: ASXL1 and spliceosome component mutations and outcomes}

MM Patnaik, E Padron, RR LaBorde, TL Lasho, CM Finke, CA Hanson, JM Hodnefield, RA Knudson, RP Ketterling, A Al-kali, A Pardanani, NA Ali, RS Komrokji and A Tefferi

Leukemia (2013) 27, 2112; doi:10.1038/leu.2013.229

Correction to: Leukemia (2013) 27, 1504-1510; doi:10.1038/ leu.2013.88

Since the publication of this article, the authors have identified an error concerning to one of the author names.

RS Komroji should have been listed as RS Komrokji.
The corrected list is shown above.

The authors would like to apologize for any inconvenience this may have caused. 